\title{
POLSZCZYZNA JAKO ŚRODOWISKO NAUCZANIA MATEMATYKI W ŚWIETLE DOŚWIADCZEŃ Z PRACY NAD PODRECCZNIKIEM DLA CUDZOZIEMCÓW
}

\begin{abstract}
Słowa kluczowe: język polski jako obcy w odmianie wyspecjalizowanej, nauczanie matematyki, podręcznik

Streszczenie. Rola polszczyzny jako środowiska w nauczaniu cudzoziemców matematyki jest zróżnicowana i zależy od etnosu oraz uprzedniego wykształcenia słuchacza. Na każdym poziomie organizacji języka istnieją w polszczyźnie źródła trudności podnoszące poziom wysiłku uczących się matematyki cudzoziemców. Nauczyciel matematyki pracujący z cudzoziemcami będzie działał skuteczniej, gdy weźmie pod uwagę te źródła trudności.
\end{abstract}

\section{STUDENCI-CUDZOZIEMCY JAKO GRUPA ODBIORCÓW TREŚCI MATEMATYCZNYCH W JĘZYKU POLSKIM}

W Studium Języka Polskiego dla Cudzoziemców Uniwersytetu Łódzkiego praca $\mathrm{z}$ tekstem specjalistycznym ma miejsce w dwóch trybach kształcenia. W trybie kształcenia językowego (tu zazwyczaj w drugim semestrze) i w trybie przygotowania merytorycznego, na przedmiotach kierunkowych. Teksty specjalistyczne z zakresu matematyki pojawiają się w procesie kształcenia kandydatów na studia ekonomiczne, politechniczne i farmaceutyczne oraz w niektórych innych grupach - w zależności od potrzeb słuchaczy.

Z myślą o głównej grupie odbiorców treści matematycznych w Studium (tj. o słuchaczach grup politechnicznych i ekonomicznych) opracowane zostały podręczniki autorstwa Danuty Wróbel, Alicji Zielińskiej i Grzegorza Rudzińskiego: Wstęp do matematyki (Wróbel, Zielińska, Rudziński 2011) oraz Matematyka po polsku (Wróbel, Zielińska, Rudziński 2013). Podręczniki te są narzędziami do

* grzegorzrudzinski@wp.pl; Zakład Lingwistyki Stosowanej i Kulturowej, Instytut Filologii Polskiej i Logopedii, Wydział Filologiczny, 90-236 Łódź, ul. Pomorska 171/173. 
rozwijania znajomości języka polskiego w zakresie zagadnień matematycznych - są to zarówno podręczniki matematyki jak i języka polskiego jako obcego. Ich odbiorcami są osoby z zagranicy scharakteryzowane w przedmowie do pierwszego podręcznika jako te, które ,z zamiarem podjęcia w Polsce studiów rozpoczynają naukę języka od podstaw; (...) które znając język polski w zakresie ogólnym muszą uzupełnić jego znajomość w zakresie matematyki; (...) które z racji różnic w programach szkolnych opanowały inny niż obowiązujący w Polsce zakres wiedzy z tego przedmiotu" (Wróbel, Zielińska, Rudziński 2011, s. 4).

Podstawowe założenie przyjęte przed stworzeniem podręczników było takie, że odbiorcy znają matematykę na poziomie obowiązującej w ich krajach matury. Oba podręczniki są więc przykładami tekstów specjalistycznych, w opracowaniu glottodydaktycznym, których nadawcy zakładają pewne minimum fachowości także po stronie odbiorcy.

\section{PRZEKAZYWANIE TREŚCI TEKSTU SPECJALISTYCZNEGO}

W artykule Tekst specjalistyczny pod lingwistyczna lupa Jerzy Lukszyn rozważając ulokowanie tekstu specjalistycznego jako manifestacji hipertekstowej normy komunikacji zawodowej między nadawcą i odbiorcą pisze:

- kontekst wiedzy odbiorcy jest wielkością zmienną, uzależnioną od treści odebranego komunikatu fachowego, który w pełni zrozumiały może być tylko w kontekście wiedzy nadawcy;

- w kontekście wiedzy odbiorcy treść tekstu specjalistycznego ulega pewnym transformacjom, takim jak symplifikacja, augmentacja, reorganizacja, deformacja, a nawet destrukcja informacji zawartej w komunikacie nadawcy (Lukszyn 2007, s. 55).

Tworząc wymienione opracowania, jako nadawcy staraliśmy się tak kreować teksty, by z repertuaru potencjalnych transformacji po stronie odbiorcy wyeliminować, na ile jest to tylko możliwe, zjawisko deformacji i destrukcji informacji. Augmentacja wiedzy podręcznikowej po stronie ucznia to największe marzenie każdego nauczyciela; reorganizację widzieliśmy jako wręcz pożądaną, bo tylko wiedza przetwarzana jest efektywnie przyswajana przez mózg (Żylińska 2013, s. 41-42), zaś symplifikację z góry akceptowaliśmy zakładając, że podręczniki mają bardziej rozwijać sprawności receptywne niż produktywne. Naszym podstawowym zadaniem było bowiem przekazanie wiedzy matematycznej za pomocą języka polskiego tj. doprowadzenie odbiorcy do rozumienia prezentowanych treści matematycznych w języku polskim.

$\mathrm{Na}$ czym polega ze strony nadawcy przekazanie, a ze strony odbiorcy zrozumienie treści tekstu specjalistycznego, którego tworzywem jest język etniczny w odmianie specjalistycznej? 


\section{Jak zauważa Sambor Grucza:}

(...) sformułowanie ,przekazywanie wiedzy” jest na gruncie lingwistyki wielce nieprecyzyjne - wiedzy nie można bowiem w dosłownym tego słowa znaczeniu w żaden sposób przekazać. (...) nie jest prawdą, że nadawca przekazuje (...) odbiorcy jakąś wiedzę specjalistyczną, bo (...) każdy rodzaj wiedzy (...) znajduje się w mózgach konkretnych ludzi, a tego, co jest w mózgu konkretnej osoby, innej osobie przekazać nie sposób. Nadawca może przekazać odbiorcy jedynie pewien obiekt sygnałowy, na przykład tekst, któremu przyporządkował w swoim mózgu określoną treść znaczeniową. To, że po odebraniu takiego tekstu specjalistycznego w mózgu odbiorcy powstaje określona wiedza specjalistyczna, wynika z tego, że tekst ten jest dla odbiorcy sygnałem, który odnosi się do określonej treści znaczeniowej (Grucza S. 2008, s. 181).

Tekst jako znak treści obecnych wyłącznie w mózgu (a raczej w umyśle) nadawcy i równocześnie jako stymulator treści w mózgu/umyśle odbiorcy może być analizowany przez językoznawcę bez konieczności koncentrowania się na owej treści. Jak pisze Franciszek Grucza:

Inherentną własnością wypowiedzi są jedynie te ich właściwości, na których opiera się ich fonemiczna i gramatyczna poznawalność, ich identyfikacja i dyferencjacja. Natomiast nie są inherentną własnością wypowiedzi te ich właściwości, które wynikają z przypisanych im funkcji znakowych (semantycznych), bo chociaż tak się zwykło mówić, to jednak wypowiedzi, rozumiane jako konkretne obiekty sygnałowe (fizykalne) w sensie dosłownym, nie zawierają w sobie żadnej treści znaczeniowej. Znaczenie jest właściwością przypisywaną wypowiedziom przez mówców-słuchaczy. A zatem znaczenie wypowiedzi nie jest właściwością przez daną wypowiedź inherentnie posiadaną, ale jest jej właściwością zależną od stosunku zajętego wobec niej przez tworzącego ją względnie interpretującego mówcę-słuchacza (Grucza F. 1983, s. 294).

W przytoczonych wypowiedziach ujawnia się rozwinięcie idei znaku, podzielonego wg. de Saussure'a na oznaczające i oznaczane, do postaci, w której oznaczane rozdziela się na oznaczane nadawcy-czyli TREŚĆ PRZEKAZYWANĄ oraz oznaczane odbiorcy czyli TREŚĆ ROZUMIANĄ.

Rys 1. Relacja umysł-znak: UN - umysł nadawcy; UO - umysł odbiorcy;

$\mathrm{TP}$ - treść przekazywana; TR - treść rozumiana

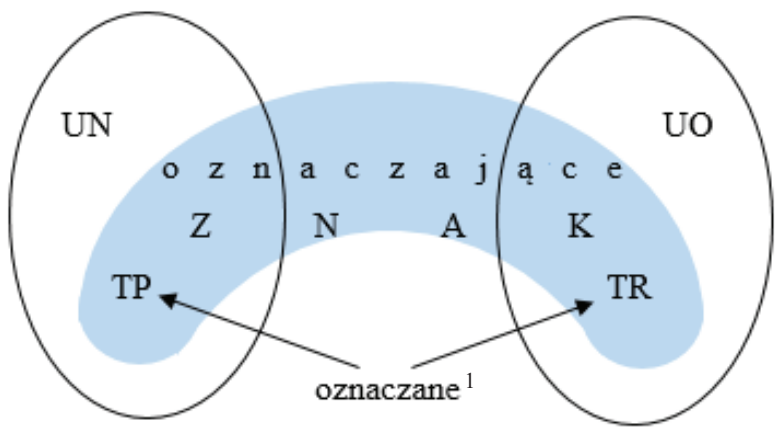

${ }^{1}$ Rysunek 1 nie rozstrzyga kwestii przynależności/nieprzynależności oznaczanego do ZNAKU poza umysłami. Rozstrzygnięcie zależy tu od ontologii przyjmowanej dla życia społecznego i rozumienia społecznego sposobu istnienia znaku. 
W świetle cytowanej wcześniej wypowiedzi Lukszyna między TP i TR mogą zachodzić następujące relacje: TP $>$ TR (symplifikacja); TP $<$ TR (augmentacja); $\mathrm{TP} \in \mathrm{TR}$ (reorganizacja); $[\mathrm{TP} \approx \mathrm{TR}] \cup[\mathrm{TP} \neq \mathrm{TR}]\left(\right.$ deformacja) i $[\mathrm{TP} \neq \mathrm{TR}]^{\wedge}[\mathrm{TP}+\mathrm{TR}<0]$ (destrukcja).

Upragniona przez nauczycieli $\mathrm{TP}=\mathrm{TR}$ zapewne w przyrodzie nie występuje. Uczestnik kursu językowego, który z jednej strony swobodnie włada wiedzą matematyczną prezentowaną $\mathrm{w}$ podręczniku, $\mathrm{z}$ drugiej zaś panuje nad polszczyzną w zakresie jej swobodnego zastosowania do komunikatów o treści matematycznej, mógłby wzbudzić w swoim umyśle treści rozumiane w bardzo wysokim stopniu zgodne $\mathrm{z}$ treściami przekazywanymi. Tacy odbiorcy są jednak $\mathrm{w}$ gronie słuchaczy SJPdC rzadkością. Nauczycielskie doświadczenie, a i wiedza płynąca z publikacji ${ }^{2}$ wskazują, że całkiem często słuchacze Studium muszą uczyć się nie tylko polskojęzycznego brzmienia znanych im z nauki szkolnej terminów, ale muszą także tworzyć od podstaw lub znacząco modyfikować treść pojęć stojących za terminami.

\section{OBSZARY POLSZCZYZNY UTRUDNIAJĄCE PRZYSWAJANIE TREŚCI MATEMATYCZNYCH PRZEZ STUDENTÓW-CUDZOZIEMCÓW}

Biorąc pod uwagę różnice między TP i TR oraz mając na względzie cel, jakim jest ich minimalizacja, traktujemy teksty podręczników matematyki dla cudzoziemców jako znaki, zaś tworzący je język jako środek ewokowania w umyśle odbiorcy treści zbliżonych do obecnych w umyśle nadawcy. Jakie są cechy tego języka i jak reaguje na nie odbiorca? Śledząc zjawiska występujące na różnych poziomach organizacyjnych polszczyzny, (kulturowym, pragmatycznym, składniowym, morfologicznym czy fonetycznym) możemy zaobserwować zjawiska bez wątpienia wpływające na jej skuteczność jako środka nauczania matematyki. Obecna w tytule artykułu metafora polszczyzny jako środowiska nauczania matematyki jest motywowana tym właśnie fenomenem: jak uwarunkowania środowiska wpływają na łatwość lub mozolność rozwoju elementów biocenozy, tak uwarunkowania językowe wpływają na stopień trudności w przyswajaniu treści matematycznych przez studentów-cudzoziemców. Opór polszczyzny na każdym z jej poziomów skutkuje ubytkami energii niezbędnej uczącemu się do opanowania treści matematycznych. Prześledźmy wybrane aspekty tego zjawiska.

${ }^{2}$ Artykuły o merytorycznym przygotowaniu młodzieży zagranicznej do studiów w Polsce to m.in.: (Rudziński 1992, s. 41-44), (Jóźwiak, Wróbel 1994, s. 155-161), (Chrupczalski 1994, s. 163-169), (Jóźwiak, Kondrak 1996, s. 221-227). Mimo upływu 20 lub więcej lat od ich publikacji odnotowane w nich obserwacje zachowują aktualność. 


\subsection{POZIOM JĘZYKOWEGO OBRAZU ŚWIATA}

Nawet w przypadku uczniów dobrze merytorycznie przygotowanych w zakresie matematyki kłopotliwe bywa identyfikowanie pojęć i terminów uwarunkowane różnicami kulturowymi. Płyną one z odmiennych w poszczególnych językach ścieżek ewolucji terminologii naukowej i odmiennych, współwarunkujących te ewolucje językowych obrazów świata. Bez trudu wyobrazimy sobie sytuację, w której polskie dziecko z dobrą znajomością angielskiego, trafiające do szkoły w Anglii może dobrze rozumieć pewne pojęcie, które prawidłowo identyfikuje z terminem liczby dodatnie, ale ma trudność z przypisaniem temu pojęciu terminu positive numbers, gdyż utożsamia przymiotnik positive $\mathrm{z}$ jego potocznymi polskimi odpowiednikami (przekonany, pewny) ${ }^{3}$, które nie wywołują skojarzenia $\mathrm{z}$ dodawaniem, na którym to skojarzeniu dotąd ustanawiało ono rozumienie tego terminu. Podobnie w przypadku pary terminów liczby ujemne i negative numbers wyraz negative kojarzy się ze szkolną ocena negatywna (a ,jedynka" to przecież liczba dodatnia), ale nie z ujmowaniem czy odejmowaniem, a tym bardziej z czymś o wartości mniejszej od zera. Sytuację dojrzalszego Polaka ratuje obecność w stylu wysokim synonimicznych par wyrażeń cechy pozytywne - cechy dodatnie i cechy negatywne - cechy ujemne, (w moim pokoleniu silnie jeszcze występuje odniesienie do fotograficznego negatywu), co tym dobitniej świadczy o istnieniu uwarunkowań lingwakulturowych w przyswajaniu terminów naukowych.

Rozumienie angielskiego wyrazu irrational 'niewymierny' poddano minitestowi. Słowo to wchodzi w skład angielskiego terminu matematycznego irrational numbers, który odnosi się do tego samego pojęcia, co polski termin liczby niewymierne (por. Jóźwiak i in. 1999, s. 62 i 75). Dwoje anglofonów, z zawodu anglistkę i informatyka, poproszono o sporządzenie map myśli dla słowa irrational i podanie jego synonimów, na co oboje mieli 10 minut. Oto wyniki:

Tabela 1. Zestawienie list synonimów pojęcia irrational

\begin{tabular}{|l|l|}
\hline \multicolumn{1}{|c|}{ respondentka } & \multicolumn{2}{c|}{ respondent } \\
\hline Illogical & Emotional \\
\hline Silly & Illogical \\
\hline Volotile & Intuitive \\
\hline stressed (acting under stress) & Unconscious \\
\hline impossible to argue with & \\
\hline Unexplainable & \\
\hline
\end{tabular}

Źródło: badanie własne (pisownia zgodna z oryginałem)

\footnotetext{
${ }^{3}$ Jak w minidialogu: A: Are you sure? B: I'm positive. Por. Gove 1993, s. 1770.
} 
Ich mapy myśli przedstawiają się następująco:

Rys. 2 Mapa myśli respondentki anglistki do pojęcia irrational

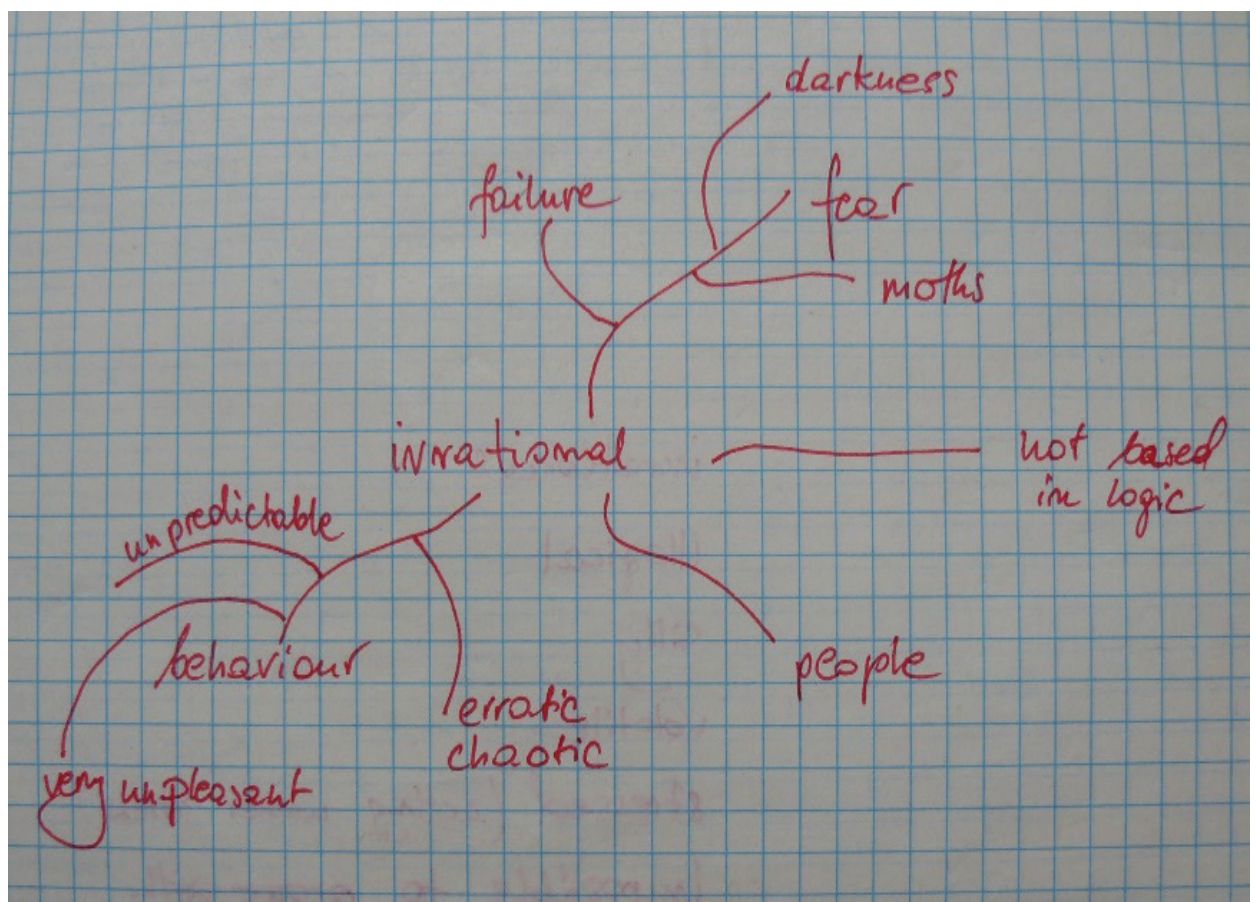

Źródło: badanie własne

Rys. 3. Mapa myśli pojęcia irrational sporządzona przez informatyka

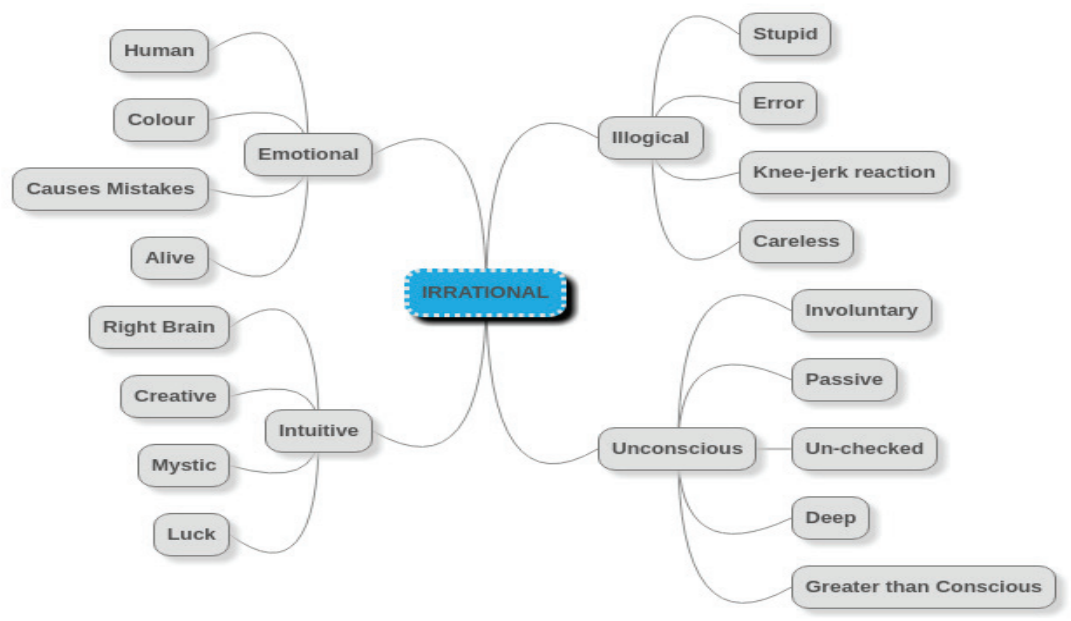

Źródło: badanie własne 
Celem powyższego, przeprowadzonego na potrzeby tego artykułu testu, nie było zdobycie wiedzy o lingwakulturowych relacjach polsko-angielskich na obszarze terminologii matematycznej, a jedynie stworzenie przystępnej ilustracji poziomu zróżnicowań lingwakulturowych i wynikających $\mathrm{z}$ tego trudności, z jakimi możemy mieć do czynienia posługując się polszczyzną jako środkiem nauczania cudzoziemców matematyki - lub, jeśli ująć to szerzej: gdy polszczyzna jako język obcy jest środowiskiem, w którym odbywa się przekazywanie treści matematycznych cudzoziemcom. Skądinąd ilustracja ta, w moim przekonaniu, świadczyć może o istnieniu obszaru badawczego na pograniczu glottodydaktyki, terminoznawstwa oraz lingwistyki kulturowej.

\subsection{POZIOM FONETYKI}

Na poziomie fonetyki zauważamy, że samo opanowanie zgodnej z normą użytkową wymowy pięciu pierwszych liczebników, odnoszących się do liczb naturalnych, wymaga od cudzoziemca zapanowania nad artykulacją następujących głosek: j, e, d, n, v, a, č ${ }^{4}, \breve{s}, y, t, r, p^{5}$, ń, ć. Tak więc opanowanie 14 zjawisk tworzących narzędzie „kreowania produktu” prowadzi do uzyskania tylko 5 jednostek „produktu docelowego”. Stosunek liczby jednostek instrumentarium (i) do liczby produktów (p), i:p wynosi tu 14:5, co musi prowadzić do refleksji nad poziomem wysiłku jakiemu mózg/umysł uczącego się musi podołać przyjmując język polski jako obcy za instrument kreowania treści matematycznych ${ }^{6}$.

W trakcie dalszej nauki proporcja ta ulega przekształceniu na korzystniejszą dla adeptów. Kolejne liczebniki wnoszą do repertuaru fonetycznego następujące głoski: 6 -ś; 7 - m; 8-o; 9 - [dź], a liczebnik dziesięć wykorzystuje wyłączne głoski z dostępnego już repertuaru, co zmienia wartość proporcji i:p z 14:5 na 18:10. W przedziale 11-20 pojawia się głoska [s] - [šesnaśće], a w przedziale 21-200 zmiękczone [v'] - [dv'jeśće]. W przedziale 201-999 dołącza kolejna głoska: [c] - [dźev’jeńcet], a liczebnik tysiąc wnosi alofon [ṇ]. Proporcja i:p osią-

\footnotetext{
${ }^{4}$ Pierwsza głoska grupy spółgłoskowej čš zapisywanej ortograficznie jako trz-. (Wyćwiczenie wzorcowej wymowy tej grupy, na tym etapie poznawania polszczyzny, gdy przyswaja on pierwsze liczebniki, należy cudzoziemcowi darować).

${ }^{5}$ Zmiękczony wariant głoski p w dominującej w potocznej polszczyźnie łodzian wymowie [p'jeńć]. Z moich obserwacji wynika, że polszczyzna potoczna przejęła mazowieckie wytrącenie miękkości z głosek wargowych, a opis opozycji fonologicznej wargowych twardych do wargowych miękkich (bały:biały, pasek:piasek, wata:wiata i geografa:geografia) przesuwa się stopniowo na grunt gramatyki historycznej.

${ }^{6}$ Oczywiście nie wierzę, by którykolwiek język etniczny był tu na tle polszczyzny mniej opresyjny. Mam natomiast nadzieję, że przyszłe pokolenia matematyków uczących cudzoziemców tknięte powyższą refleksją będą, tak jak moje dwie znakomite koleżanki, umiały docenić językowy i glottodydaktyczny aspekt specjalistycznego kształcenia cudzoziemców.
} 
ga wartość 22:1000. Kolejną innowację repertuaru fonetycznych instrumentów - głoskę [1'] - wprowadza dopiero liczebnik milion. Głoskę [b'] bilion, a głoski [k] i [f] kwadrylion. Zauważmy, że wyartykułowanie w języku polskim tak wielkiej liczby nazw elementów zbioru liczb naturalnych nie wymaga znajomości całego repertuaru polskich głosek. Innymi słowy, polszczyzna jako środowisko nauczania matematyki w relacji środków fonetycznych do zasobu liczebników głównych dysponuje przewagą środków dostępnych nad niezbędnymi.

\subsection{POZIOM SKŁADNI}

W zakresie uwarunkowań składniowych, wąskim, ale sprawiającym wiele kłopotów zjawiskiem powiązanym z nauczaniem matematyki jest wymóg użycia innej formy fleksyjnej po liczebnikach z przedziału 2-4 lub liczebnikach złożonych zakończonych w przedziale $2-4$, niż po liczebnikach z przedziałów 5-21, 25-31, 35-41 itd. Iwona Słaby-Góral przedstawiła interesującą analizę możliwego ujęcia metodycznego tego obszaru polszczyzny. Zaproponowała jednak rozwiązania dostępne dla słuchaczy posługujących się dość swobodnie językiem w opisie rutyny dnia powszedniego, tj. mających za sobą co najmniej 6 tygodni (około 140 godzin) nauki (Słaby-Góral 1998). Tymczasem matematyka w rozkładzie zajęć pojawia się prawie jednocześnie z językiem polskim (po 25-30 godzinach), gdy nauczyciel ma do dyspozycji ,niewiele poza konstrukcją najprostszego zdania podmiotowo-orzecznikowego typu $a$ jest $b$ (...) i jego negacji bez kwantyfikacji [oraz] czasownikami być, mieć, nazywać się i to nie we wszystkich osobach czasu teraźniejszego" (Wróbel 1991, s. 64). A wymienione zjawisko składniowe niezbędne jest już na pierwszych zajęciach z matematyki do prawidłowego odczytywania ułamków: cztery trzecie, ale dwadzieścia pięć trzecich. Mamy tu zatem taką sytuację, jakby z racji uwarunkowań organizacyjnych, to nie język polski był instrumentem nauczania matematyki, ale kod matematyki stawał się środkiem oswajania adeptów z nowymi zjawiskami języka polskiego. Najlepsze wyobrażenia o kształceniu zagranicznych kandydatów na studia w Polsce zawsze zresztą nakładały na nauczycieli dążenie do osiągnięcia takiej korelacji między przedmiotami kierunkowymi a językiem polskim, by zjawisko synergicznego wspierania rozwoju językowego było jak najpełniejsze ${ }^{7}$.

W opracowanym przez nas podręczniku (2011) systematyczne czytanie ułamków, realizowane w lekcji czwartej, jest równocześnie intensywnym ćwiczeniem poświęconym opanowaniu wymienionego wyżej zjawiska gramatycznego.

${ }^{7}$ W Repozytorium Uniwersytetu Łódzkiego dostępne są na ten temat liczne artykuły z opublikowanych dotychczas tomów „Kształcenia Polonistycznego Cudzoziemców” (Acta Universitatis Lodziensis. Kształcenie Polonistyczne Cudzoziemców. Repozytorium UŁ). 
Ubocznym efektem, towarzyszącym powtarzaniu treści matematycznych winno być w tym przypadku wyćwiczenie prawidłowej dystrybucji końcówek dopełniacza liczby mnogiej przymiotników w rodzaju żeńskim, co powinno też korzystnie współkształtować poprawność gramatyczną w całym obszarze fleksji imiennej.

\subsection{POZIOM PRAGMATYKI}

Na zjawisko nadmiaru środków języka naturalnego względem kodu matematyki (podobne do przedstawionego wcześniej w obszarze fonetyki), obecne na poziomie pragmatyki zwraca uwagę Danuta Wróbel, gdy rejestruje pragmatyczne realizacje funktora implikacji oraz odpowiadającego mu zdania o schemacie $\mathrm{p} \Rightarrow \mathrm{q}$ :

Zakłada się, że jest to schemat zdania warunkowego, które czytamy Jeżeli $P$ to $Q(P, Q$

- zdania w sensie logicznym). Okazuje się, że spójnik Jeżeli..., to... ma wiele znaczeń

w języku polskim:

nieprawda, że $P$ i nie $Q$,

nie jest możliwe, że $P$ i nie $Q$,

ze zdania $P$ wynika zdanie $Q$,

to, że $P$ jest przyczyną $Q$. (Wróbel 1991, s. 64)

Obserwowany na tym poziomie nadmiar składników językowego środowiska nad liczbą pożądanych w procesie kształcenia elementów treści przekazywanej i rozumianej może uruchamiać u odbiorcy treści matematycznych ujętych w języku naturalnym liczne trudności. Jeśli nauczyciel matematyki, dla którego polszczyzna jest językiem rodzimym, zbyt swobodnie posługuje się jej rozlicznymi środkami wyrazu, wywołuje u obcojęzycznego adepta wrażenie chaosu i nieogarnionej wariantywności języka docelowego ${ }^{8}$.

Pracując nad pierwszym z wymienionych na wstępie podręczników (Wróbel, Zielińska Rudziński 2011) szczególną uwagę zwróciliśmy właśnie na jak najdalej idące, lecz z punktu widzenia matematyki dopuszczalne, ograniczenie tej wariantywności. Jej całkowita redukcja nie jest ani możliwa, ani słuszna. Student, od którego wymaga się przede wszystkim rozumienia prezentowanego w podręczniku materiału, nie ma obowiązku czynnego opanowania wszystkich wariantów. Nauczyciel, z kolei, po nadmiernej redukcji powszechnie w kodzie matematyki występujących form musiałby przechodzić intensywny trening, by w swoich

\footnotetext{
${ }^{8} \mathrm{Na}$ marginesie przywołanych rozważań D. Wróbel wskazuje, że ,język naturalny pełni w matematyce rolę pomocniczą w stosunku do zapisów formalnych. Inaczej mówiąc, jedynie ważny jest zapis formalny (...)" - op. cit., s. 65 - to jednak, nie da się komunikacji nauczyciela matematyki z grupą obcojęzycznych adeptów sprowadzić do czystego kodu nauczanej dziedziny. Ile spontanicznego nadmiaru środków językowych może nawet wbrew woli doświadczonych nauczycieli przenikać do nauczanego materiału przekonaliśmy się pracując nad naszym podręcznikiem.
} 
spontanicznych wypowiedziach nie używać żadnych wariantów spoza podręcznika. Prowadziłoby to do kreacji nienaturalnych zachowań komunikacyjnych na lekcjach matematyki i nadmiernego ograniczenia repertuaru językowych formuł matematycznych w biernym zasobie polszczyzny naszych studentów.

\section{PIERWSZY ROZDZIAL PODRECZNIKA WSTĘP DO MATEMATYKI JAKO PRZYKLAD TEKSTU SPECJALISTYCZNEGO SPRZYJAJĄCEGO PRZYSWAJANIU TREŚCI MATEMATYCZNYCH}

W pierwszej lekcji Wstępu do matematyki materiał językowy składa się w zakresie leksyki ze słownictwa prezentowanego przed rozpoczęciem kursu matematyki na zajęciach z języka polskiego (datum leksykalne) i z nowych słów (novum leksykalne) wprowadzonych w celu przekazania 23 pojęć matematycznych utworzonych z 14 słów. W zbiorze nowo wprowadzonej leksyki rzeczowniki stanowią połowę materiału, czasowniki są trzy, przymiotniki cztery:

Tabela 2. Nowo wprowadzona leksyka pierwszego rozdziału (novum leksykalne)

\begin{tabular}{|l|l|l|}
\hline Części mowy & \multicolumn{1}{|c|}{ Leksemy } & \multicolumn{1}{c|}{ Obslugiwane pojęcia } \\
\hline rzeczowniki & $\begin{array}{l}\text { cyfra, } \\
\text { element, } \\
\text { fałsz, } \\
\text { liczba, }\end{array}$ & $\begin{array}{l}\text { cyfra, jednocyfrowy, dwucyfrowy, trzycyfrowy, } \\
\text { element, element zbioru, } \\
\text { fałsz, } \\
\text { liczba, liczba całkowita, liczba dwucyfrowa, liczba jedno- } \\
\text { cyfrowa, liczba naturalna, liczba nieparzysta, liczba parzy- } \\
\text { sta, liczba trzycyfrowa, zbiór liczb, zbiór liczb całkowitych, } \\
\text { zbiór liczb naturalnych, zbiór liczb nieparzystych, zbiór liczb } \\
\text { parzystych, } \\
\text { minus, } \\
\text { prawda, } \\
\text { zbiór, element zbioru, należeć do zbioru, tworzyć zbiór, zbiór } \\
\text { liczb, zbiór liczb całkowitych; }\end{array}$ \\
& $\begin{array}{l}\text { minus, } \\
\text { prawda, } \\
\text { zbiór; }\end{array}$ & $\begin{array}{l}\text { należeć do zbioru, } \\
\text { oznaczać, } \\
\text { tworzyć zbiór; }\end{array}$ \\
\hline czasowniki & $\begin{array}{l}\text { należeć do } \\
\text { oznaczać, } \\
\text { tworzyć; }\end{array}$ & $\begin{array}{l}\text { liczba całkowita, zbiór liczb całkowitych, } \\
\text { liczba naturalna, zbiór liczb naturalnych, } \\
\text { liczba nieparzysta, zbiór liczb nieparzystych, } \\
\text { liczba parzysta, zbiór liczb parzystych. }\end{array}$ \\
\hline przymiotniki & $\begin{array}{l}\text { całkowity, } \\
\text { naturalny, } \\
\text { narzarzysty, }\end{array}$
\end{tabular}

${ }^{a}$ Czasowniki o składni przyimkowej - termin za (Lesz-Duk 1988) - traktowane są na gruncie glottodydaktyki polonistycznej jako integralne jednostki, podobnie jak czasowniki frazalne (frazal verbs) są traktowane przez anglistów. Stąd nie uwzględnia się przyimka do jako odrębnej części mowy. 
W warstwie słownictwa prezentowanego na języku polskim (datum leksykalne) obecne są wybrane liczebniki główne i porządkowe z zakresu od zera do 1219 oraz następujące słowoformy (w kolejności wystąpienia): to, sq, wszystkie, mamy, nie, ma, jest, piszemy, symbolami, czytamy, też, nowe, słowa, patrz, ćwiczenia, napisać, po polsku, czy, przykład. Rozdział zawiera ok. 360 wyrazów tekstowych zapisanych ortograficznie lub cyframi i symbolami, jak symbol znaku równości $(=)$, minus $(-), \pi$ lub $\in$ 'należy $d o$ '. Rozproszenie novum leksykalnego $\mathrm{w}$ datum utrzymuje się na ogół w proporcji lepszej niż 1 wyraz nowy na 10 znanych. Jeśli pominąć tytuł rozdziału, w którym relacja novum do datum wynosi 5:0 - pierwsze wystąpienie nowego słowa (cyfry) jest trzynastym wyrazem graficznym tekstu, drugie wystąpienie słowa z zakresu novum (liczby) jest 31 wyrazem graficznym tekstu.

W zakresie obsługującej pierwszy rozdział podręcznika gramatyki mamy do czynienia z obiema liczbami, zarówno w paradygmacie werbalnym jak i imiennym, choć dotyczy to bardzo małej liczby słowoform. W zakresie deklinacji występują: MIANOWNIK (To sa cyfry; To sa liczby; To nie sq wszystkie liczby; Minus dwadzieścia jeden to nie jest liczba naturalna; To sa liczby naturalne; C to jest zbiór...; Liczba 50 ma dwie cyfry; To jest liczba dwucyfrowa; Wszystkie liczby naturalne tworza zbiór...; Dziewiętnaście należy do zbioru $N$; Czy to jest prawda czy falsz?); BIERNIK (Mamy dziesięć cyfr; Liczba 50 ma dwie cyfry; Liczba 8 ma jedna cyfrę; Wszystkie liczby naturalne tworza zbiór liczb naturalnych; Wszystkie liczby catkowite tworza zbiór liczb calkowitych; Zbiór liczb catkowitych oznaczamy tez Z.); DOPEŁNIACZ (Wszystkie liczby naturalne tworzq zbiór liczb naturalnych; $N$ to jest zbiór liczb naturalnych; Dziewiętnaście należy do zbioru $N$; Dziewiętnaście to jest element zbioru $N$; zbiór liczb calkowitych), NARZĘDNIK (piszemy symbolami; Sto dwanaście jest liczba naturalna).

W komponencie informacyjnym - termin za (Nocoń 2009, s. 179) - tekstu pierwszego rozdziału występuje wyłącznie tryb orzekający (zdania oznajmujące i przeczące - te ostatnie tworzone wyłącznie z partykułą nie). W komponencie zadaniowym jedno wypowiedzenie jest pytaniem o rozstrzygnięcie, a tryb rozkazujący występuje w poleceniach zadań w postaci zredukowanej do bezokolicznika (Napisać po polsku; Napisać symbolami).

\section{DIALOG INTERDYSCYPLINARNY JAKO DROGA DO OBCOJEZZYCZNEGO TEKSTU SPECJALISTYCZNEGO}

Wspólne tworzenie podręcznika przez matematyczki i polonistę było procesem obfitującym w zaskakujące dla autorów sytuacje wzajemnego odkrywania nieoczywistości proponowanych rozwiązań. Przyczyną zaskoczeń po stronie polonisty był repertuar form funkcjonujących w matematycznym dyskursie szkol- 
nym i akademickim. Możliwość jego samodzielnego przestudiowania wiązałaby się z koniecznością powrotu do ławy szkolnej. Publikacje językoznawcze na ten temat są interesujące acz nieliczne. Warto tu przywołać opracowanie analizujące wykłady prof. Zofii Krygowskiej z metodyki matematyki (Ożdżyński, Treliński 1982) i artykuły pisane przez osoby praktykujące nauczanie cudzoziemców w zakresie matematyki (Czernik 1988), (Wróbel 1991).

Pierwszym zaskoczeniem była propozycja, by polecenia w zadaniach redukować do formy bezokolicznika, co na tle przyzwyczajenia do form grzecznościowych z Proszę + bezokolicznik zdawało się być wręcz obcesowe, a co - jak przekonały mnie koleżanki - jest zgodne z praktykowanym w akademickich podręcznikach matematyki sposobem nawiązywania interakcji z czytelnikiem-studentem. Drugim, nieco zabawnym, konstatacja, że $\pi$ jest liczebnikiem o własnościach składniowych takich jak 5, 6, 7 .., a nie takich jak 2, 3, 4- ułamek $\frac{\pi}{4}$ czytamy $p i$ czwartych, a nie * pi czwarte. Trzecim zaskoczeniem, było bogactwo repertuaru wariantów powierzchniowych realizujących ten sam logiczny model wypowiedzenia - $\mathrm{i}$ to, nie w zakresie operacji umysłowych tak względnie zaawansowanych jak wspomniane wyżej $\mathrm{p} \Rightarrow \mathrm{q}$, ale $\mathrm{w}$ zakresie najprostszej równoważności a=b:

$\mathrm{N}$ to zbiór liczb naturalnych;

$\mathrm{N}$ to jest zbiór liczb naturalnych;

$\mathrm{N}$ to symbol zbioru liczb naturalnych;

$\mathrm{N}$ to jest symbol zbioru liczb naturalnych;

$\mathrm{N}$ jest symbolem zbioru liczb naturalnych;

Symbolem zbioru liczb naturalnych jest N;

Zbiór liczb naturalnych oznaczamy $\mathrm{N}$;

$\mathrm{N}$ oznacza zbiór liczb naturalnych;

Zbiór liczb naturalnych oznaczamy symbolem N;

Symbolem N oznaczamy zbiór liczb naturalnych;

$\cdots$

Zarówno autorkom matematyczkom, jak i współautorowi poloniście zależało na wprowadzeniu do podręcznika takiego ograniczonego repertuaru form składniowych, który będzie optymalny dla początkowego etapu nauczania. Zaskoczeniem dla autorek była jednak gramatyczna złożoność form spontanicznie przez Nie używanych, gdy okazuje się, że najnaturalniejszy, zdawałoby się, komunikat: Symbolem N oznaczamy zbiór liczb naturalnych, po wzięciu pod językoznawczą (nawet nie najsilniej powiększającą) lupę przedstawia się jako fenomen złożony, zawierający:

- zdanie o przestawnym szyku,

- zdanie bez wydzielonego w odrębny leksem podmiotu,

- zdanie z dopełnieniem dalszym w pozycji jaką dominujące języki światowe rezerwują właśnie dla tego, tu ukrytego (z niejasnych dla słuchacza-cudzoziemca przyczyn) podmiotu,

- z szykiem przymiotnika typowym dla terminologii naukowej, a nie dla mowy potocznej, 
- z konstrukcją przydawki rzeczownej,

- z fleksją i składnią pomijającymi formy mianownika - a więc bez form uznawanych

za podstawowe, ale

- z formą biernika homofoniczną wobec mianownika (czego akurat ani natywni polono-

foni ani adepci polszczyzny zwykle nie odróżniają),

- z trzema przypadkami zależnymi: biernik, dopełniacz, narzędnik,

- $\mathrm{z}$ reprezentacją form liczby pojedynczej i mnogiej paradygmatu imiennego,

- $\mathrm{z}$ czasownikiem w pragmatycznej funkcji pluralis modestiae.

Refleksja, że każdy z wymienionych wyżej fenomenów może być przedmiotem odrębnej jednostki lekcyjnej nie działała jednak paraliżująco, mimo, że taki węzeł gramatycznych trudności byłby nieakceptowalny w procedurze nauczania języka polskiego jako obcego skierowanej na rozwój czynnej komunikacji. Frapującym bowiem odkryciem dla polonisty było to, że w praktyce nauczania cudzoziemców matematyki za pośrednictwem polszczyzny w pewnych obszarach studenci mogą przeskakiwać ponad trudnościami wynikającymi ze złożoności zjawisk językowych dzięki dysponowaniu czystym kodem symboli matematycznych, w poważnym stopniu niezależnym od jakiegokolwiek języka etnicznego. Przykładowo: związek wyrazów pięć siódmych to liczebnik główny w mianowniku i liczebnik porządkowy w dopełniaczu liczby mnogiej, rodzaju żeńskiego. Lecz sprowadzony na poziomie rozumienia do formuły $\frac{a}{b}$ nie sprawia już trudności innych niż czysto artykulacyjne. Nie przeczy to zjawisku zależności sukcesu w uczeniu się matematyki za pomocą polszczyzny od etnosu ucznia. Biegłość w matematyce poprzedzająca przyjście na kurs w Studium Języka Polskiego dla Cudzoziemców UŁ w wysokim stopniu ogranicza trudności, ale ich nie znosi. Najlepszym przykładem tej sytuacji są niektórzy studenci wietnamscy bardzo biegle władający w piśmie kodami matematyki i logiki formalnej, ale nie umiejący do końca kursu przebić głuchoty fonologicznej na poziomie odróżniania artykulacji [čšy] od artykulacji [šeść], z których wychwytują jedynie element szumiący szczelinowy, co poważnie utrudnia im odniesienie sukcesu edukacyjnego po wejściu w środowisko polskie poza Studium.

Dla moich współautorek przygodą językoznawczą okazało się odkrycie mechanizmu interferencji wewnątrzjęzykowej, na przykładzie konfuzji wywoływanej zrozumieniem przez studentów-cudzoziemców pewnych zasad dystrybucji rodzaju gramatycznego, gdy konstrukcja składniowa elementarnej definicji, coś jest czymś, zdaje się tym zasadom przeczyć. Po opanowaniu sprawności predykacji, że liczba (ta liczba, rodzaj żeński) jest dodatnia (wyrazowi w rodzaju żeńskim towarzyszy orzecznik w rodzaju żeńskim), oraz: Ten ułamek jest skracalny (gdzie wyraz w rodzaju męskim orzeka coś o desygnacie wyrazu w rodzaju męskim), tudzież, że: Zdanie jest fatszywe lub prawdziwe - cudzoziemiec staje wobec konieczności poradzenia sobie z zagadką dlaczego ułamek (masc.) jest liczba niewymierna (fem.), liczba (fem.) jest czynnikiem (masc.), a ta sama figura geometrycz$n a(f e m$.) rzutowana na płaszczyznę prostopadłą do jej płaszczyzny jest odcinkiem 
(masc.), a rzutowana na płaszczyznę równoległa jest kołem (neutr.). Dostrzeżenie i samodzielne opisanie zasady rozplątującej ten węzeł cudzoziemskich konfuzji było podczas jednej z sesji pracy nad podręcznikiem miłą rozrywką dla moich współautorek.

Praca nad podręcznikiem polegała na dwustronnym korygowaniu propozycji. W pierwszej fazie spontanicznie tworzony komponent informacyjny podręcznika był najpierw rewidowany przez polonistę w kierunku redukcji liczby wariantów składniowych tudzież eliminowania takiej gramatycznej wielowarstwowości jaka została zilustrowana powyżej. W drugiej, rezultat pracy polonisty był kontrolowany pod kątem naruszeń logiki formalnej, co zdarzało się przy próbach uproszczenia brzmień definicji, lub pod kątem odstępstw od pragmatyki dyskursu dydaktycznego uprawianego w matematyce. W trzeciej fazie do komponentu informacyjnego dodawane były zadania służące egzekwowaniu tej wiedzy merytorycznej, której utrwalenie było niezbędne dla skuteczności nauczania, oraz ćwiczenia językowe poświęcone tym zagadnieniom, których kształt w polszczyźnie z przyczyn logiczno-formalnych lub pragmatycznych nie mógł być sprowadzony do postaci przyswajalnej bez odczucia bariery językowej. Podręcznik nie wyeliminował więc wszystkich wynikających z natury języka polskiego trudności jakie towarzyszą nauczaniu matematyki cudzoziemców w środowisku polskim. Wierzymy jednak, że sposób uwrażliwiania użytkowników podręcznika (zarówno studentów jak i nauczycieli) na miejsca trudne polszczyzny ułatwi radzenie sobie z trudnościami, których źródłem w polskojęzycznym dyskursie matematycznym może być sama polszczyzna.

\section{BIBLIOGRAFIA}

Acta Universitatis Lodziensis. Kształcenie Polonistyczne Cudzoziemców. Repozytorium Uniwersytetu Łódzkiego, http://dspace.uni.lodz.pl:8080/xmlui/handle/11089/1350.

Chrupczalski A., 1994, Przygotowanie merytoryczne kandydatów ze Wschodu na studia w Polsce, w: J. Mazur (red.), Merytoryczne ksztatcenie Polaków ze Wschodu. Lublin, s. 163-169.

Czernik B., 1988, Z prac nad stownikiem dydaktycznym dla cudzoziemców. Dobór i układ treści $w$ matematycznym słowniku minimum, „Acta Universitatis Lodziensis. Kształcenie Polonistyczne Cudzoziemców” t. 1, s. 33-46.

Gove Ph. B. (red.), 1993, Webster's Third New International Dictionary of the English Language Unabridged. Springfield-Cologne-Fulda.

Grucza F., 1983, Zagadnienia metalingwistyki. Lingwistyka - jej przedmiot, lingwistyka stosowana, Warszawa.

Grucza S., 2008: „Teksty specjalistyczne”: językowe eksponenty wiedzy specjalistycznej, „Języki Specjalistyczne" t. 8, s. 181-193.

Jóźwiak Z., Wróbel D., 1994, Organizacja nauczania matematyki i sprawdzania wiadomości studentów w ramach sesji orientacyjnej, w: J. Mazur (red.), Merytoryczne kształcenie Polaków ze Wschodu, Lublin, s. 155-161. 
Jóźwiak Z., Kondrak L., 1996, Testy z matematyki a sprawność językowa i wiedza merytoryczna studentów SJPdC, „Acta Universitatis Lodziensis. Kształcenie Polonistyczne Cudzoziemców” t. $7 / 8$, s. 221-227.

Jóźwiak Z., Kondrak L., Wróbel D., Zielińska A., 1999, Słownik polsko-angielsko-francusko-rosyjski podstawowych terminów matematycznych z wykazami haset angielsko-polskim, francusko-polskim, rosyjsko-polskim oraz tablica symboli, Łódź.

Lesz-Duk M., 1988, Czasowniki o składni przyimkowej w języku polskim, Częstochowa.

Lukszyn J., 2007, Tekst specjalistyczny pod lingwistyczną lupa, „Języki Specjalistyczne” t. 7, s. $51-70$.

Nocoń J., 2009, Podręcznik szkolny w dyskursie dydaktycznym - tradycja i zmiana, Opole.

Ożdżyński J., Treliński G., 1982, Niektóre cechy wypowiedzi wykładowej. Na przykładzie wykładów $z$ dydaktyki matematyki, ,Zeszyty Naukowe WSP w Szczecinie. Prace Wydziału Humanistycznego" t. 11, s. 257-285.

Rudziński G., 1992, Młodzież polonijna w świetle wyników sesji orientacyjnej w SJPdCUt, w: J. Mazur (red.), Problemy kształcenia Polaków ze Wschodu, Lublin, s. 41-44.

Słaby-Góral I., 1998, Analiza możliwości funkcjonalnego wprowadzenia form fleksyjnych w grupach studentów cudzoziemców uczących się języka polskiego (na podstawie wybranych zwiazków składniowych z liczebnikami głównymi, „Acta Universitatis Lodziensis. Kształcenie Polonistyczne Cudzoziemców" t. 10, s. 353-359.

Wróbel D., 1991, Niedefinicyjne wprowadzanie pojęć matematycznych, „Acta Universitatis Lodziensis. Kształcenie Polonistyczne Cudzoziemców" t. 3, s. 63-74.

Wróbel D., Zielińska A., Rudziński G., 2011, Wstęp do matematyki. Podręcznik dla cudzoziemców, Łódź.

Wróbel D., Zielińska A., Rudziński G., 2013, Matematyka po polsku. Podręcznik dla cudzoziemców, Łódź.

Żylińska M., 2013, Neurodydaktyka. Nauczanie i uczenie się przyjazne mózgowi, Toruń.

Grzegorz Rudziński

\section{POLISH LANGUAGE AS AN ENVIRONMENT OF TEACHING MATHEMATICS TO FOREIGNERS IN THE LIGHT OF EXPERIENCE OF WORKING ON THE MANUAL FOR FOREIGNERS} manual

Keywords: Polish as a foreign language, LSP, teaching mathematics to foreigners in Poland,

Summary. The role of the Polish language as an environment of teaching mathematics to foreigners depends on ethnos and prior education of the listener. At every level of the organization of language exists in the Polish language the source of the difficulty to raise the level of effort studying mathematics foreigners. Maths teacher working with foreigners will work more efficiently when he/ she takes into account the sources of difficulty. 